\title{
The House on Bayou Road: Atlantic Creole Networks in the Eighteenth and Nineteenth Centuries
}

\section{Pierre Force}

In 1813 a free man of color named Charles Decoudreau living in New Orleans went to court to repossess a house on the edge of town he had sold two years before to Charles Lamerenx, a white man from Saint Domingue. Despite being on opposite sides of a racial divide, the men and their families had much in common as "Atlantic creoles." In this study, I test the meaning and explanatory power of Ira Berlin's concept of "Atlantic creole" by telling the story of two families, one "black" and one "white," whose paths briefly crossed in New Orleans in 1811.

Berlin's work on "Atlantic creoles" is a powerful intervention in this field because it begins by telling a familiar story and proceeds with a much less familiar one. The familiar story is that of Africans being forcibly taken to America and stripped of their African identities, and developing a new creole or African American culture that was the product of their experience as slaves working in the plantations. Important as this story is, it captures "only a portion of the history of black life in colonial North America, and that imperfectly." The story as usually told begins with an unadulterated "African" identity that was somehow erased or transformed by the experience of slavery and gave way to a creole identity that was a mix of various African, European, and Native American components. Inverting this story of origins, Berlin shows that the Africans of the charter generations were always already creole: their experiences and attitudes "were more akin to that of confident, sophisticated natives than of vulnerable newcomers." Atlantic creoles originated in the encounters between Europeans and Africans on the western coast of Africa, starting in the fifteenth century, well before Christopher Columbus sailed to America. In a few coastal enclaves, groups of multilingual Eurafricans acted as intermediaries between Europeans, North African Muslims, and inland Africans. The first generations of slaves brought to America came from these enclaves. Atlantic societies predating the plantation system were societies with slaves rather than slave societies, and there were important social

Pierre Force is the dean of humanities and a professor of French and history at Columbia University.

For their comments and suggestions, thanks to Christopher L. Brown, Jacques de Cauna, Christiane DemeulenaereDouyère, Daniel Desormeaux, Souleymane Bachir Diagne, Mamadou Diouf, Madeleine Dobie, Eric Foner, Virginia Meecham Gould, Mary Niall Mitchell, Emmanuelle Saada, and Rebecca Scott. For their help in accessing and interpreting archival material, thanks to Léopold Darritchon, Marianne Simpson, Denis Dufourcq, François Dufourcq (La Bastide Clairence), Alina Arce (Havana), Esther González Pérez (Seville), Kara Brockman, Jonn Ethan Hankins, and Gregory Osborn (New Orleans). Last but not least, thanks to Jennifer Garnier Morris for sharing the results of her genealogical research on the Decoudreau and Trevigne families, and to Alina Arce and Maite Delamerens for doing the same regarding the Lamerenx family.

Readers may contact Force at pf3@columbia.edu. 
and cultural similarities between the European enclaves on the western coast of Africa (Elmina and Saint-Louis, for example) and the European enclaves in North America and the Caribbean (New Orleans, Charleston, Cartagena, and Cap-Français, for example). Those who circulated among these enclaves, whether slave or free, were likely to be multilingual and highly skilled. Manumissions were frequent, and, no matter how brutal master-slave relations may have been, the distance between master and slave was not incommensurable. Berlin explains his choice of the term creole by referring to the etymology of the Portuguese term crioulo meaning, according to him, "a person of African descent born in the New World." Among the competing and mutually exclusive definitions of the term, he uses creole to mean "black people of native American birth," while Atlantic creole includes "those who by experience or chance, as well as by birth, became part of a new culture that emerged along the Atlantic littoral-in Africa, Europe, or the Americas-beginning in the 16th century." 1

In fact, the word creole, without the Atlantic qualifier, and within the range of its contested meanings, is a good guide for understanding the complexity of the new Atlantic culture to which Berlin is referring. Even though the etymology of the words criollo (Spanish) and crioulo (Portuguese) has not been established with certainty, a few elements are clear. The word creole comes from the Latin creare (to give birth, to procreate) via the Spanish and Portuguese criar (to feed, to bring up). It passed from Spanish and Portuguese into French and English. It seems to have originated in the context of the slave trade, possibly in the Portuguese pidgin that was employed on the West African coast during the fifteenth century (in that case, the word creole would itself be a creole word). Early meanings of the term include, "a slave born in his master's house" (as opposed to purchased elsewhere), "a native" (of any land), "a person born in the colony of European or African parents" (in other words, a native whose parents are not native), and "a slave born in the colony" (as opposed to Africa). This quick overview shows how the various, sometimesincompatible meanings were interrelated. From what seems to be the original meaning ("native-born slave"), the broader meaning of natural-born was derived (as the president of the United States must be a "natural-born citizen," that is, a creole). This derivation is similar to the one observed in the Latin words verna (a slave born in his master's house) and vernaculus (vernacular, or native). Finally, a sense pervaded that the culture into which creoles were born was new and distinctive, a fact that was alternatively perceived with shame and pride. $^{2}$

1 Ira Berlin, Many Thousands Gone: The First Two Centuries of Slavery in North America (Cambridge, Mass., 1998), esp. 17-28; Ira Berlin, "From Creole to African: Atlantic Creoles and the Origin of African-American Society in Mainland North America," William and Mary Quarterly, 53 (April 1996), 251-88, esp. 253-54, 253n5, $254 \mathrm{n} 8$. See also Linda M. Heywood and John K. Thornton, Central Africans, Atlantic Creoles, and the Foundation of the Americas, 1585-1660 (Cambridge, Eng., 2007). The term Eurafrican is from George E. Brooks, Eurafricans in Western Africa: Commerce, Social Status, Gender, and Religious Observance from the Sixteenth to the Eighteenth Century (Athens, Ohio, 2003).

2 The word creole was used in a pejorative sense by the slaves themselves to designate those born in the colony as opposed to those born in Africa. See Eva Martha Eckkrammer, "On the Perception of 'Creole' Language and Identity in the Netherland Antilles," in A Pepper-Pot of Cultures: Aspects of Creolization in the Caribbean, ed. Gordon Collier and Ulrich Fleischmann (Amsterdam, 2003), 85-108, 90. Dieter Woll, "Esp. criollo y port. crioulo: Volviendo a la cuestión del origen y la historia de las dos palabras" (On the Spanish criollo and the Portuguese crioulo: Back to the question of the origin and history of these two terms), in Latinitas et Romanitas. Festschrift für Hans Dieter Bork zum 65. Geburtstag (Latinitas and Romanitas. Festschrift for Hans Dieter Bork on his 65th birthday), ed. Annegret Bollée and Johannes Kramer (Bonn, 1997), 517-35. As Rodolphe Lucien Desdunes wrote of a resident of the area, "His pride in being Creole was more dear to him than his being a Louisianan." Rodolphe Lucien Desdunes, Our People 
Berlin's focus is on African American society, and his definition of creole is consistent with traditional English and American usage (creole was most often used in the expression creole negroes, to designate black slaves born in the colony). However, as we have just seen, the word creole was historically defined by slavery, but its other uses, while retaining the original connection, were not restricted to it, especially in Spanish, Portuguese, and French. In eighteenth-century Saint Domingue, the word creole was used to designate any person, black or white, slave or free, born in the colony. In an 1802 proclamation, Toussaint Louverture, then leader of the island, used the word to mean every individual on the island (black or white) born in the colony or in Africa. During the debates in the United States that accompanied the accession of Louisiana to statehood in 1812, the word was sometimes used to designate natural-born free Louisianans, some of whom were of African descent. I submit that Atlantic creole can be used to capture a very specific but hard-to-grasp way of life that was a coincidence of opposites: it was tied to slavery but not restricted to it; it was born of commerce and migration but understood itself as "native"; it was deeply local yet displayed remarkable similarities across the Atlantic world. ${ }^{3}$

The concept of "Atlantic creole" is at work, explicitly or implicitly, in a few recent studies that focus on family histories. Rebecca Scott and Jean Hébrard have traced the "Atlantic creole itinerary" of a mixed-race family over several generations during the long nineteenth century. Martha Hodes has told the story of a white working-class woman who married a black seafarer in New Hampshire and started a new life with him in the Cayman Islands. Daniel Schafer has reconstructed the life of Anna Madgigine Jai Kingsley, "African princess, Florida slave, plantation slaveowner." These micro-historical studies, based in part on interviews with descendants and supported by extensive genealogical research, are written in a quasi-novelistic mode. One might be tempted to dismiss this kind of work as pandering to the popular obsession with genealogy and to argue that studying the history of one family will never yield any generalizable results. I contend, on the contrary, that these studies have much to tell us about the complexity of Atlantic creole culture and its survival well into the nineteenth century. ${ }^{4}$

The works mentioned above owe a lot to the techniques of microstoria and their appropriation by members of the Annales school in the 1990s: a method characterized by an

\footnotetext{
and Our History, ed. and trans. Dorothea Olga McGants (Baton Rouge, 1973), 21. This book was originally published as Rodolphe Lucien Desdunes, Nos Hommes et notre histoire (Our people and our history) (Montreal, 1911).

3 "Proclamation of Toussaint Louverture, Governor of St. Domingo," Alexandria Times; and District of Columbia Daily Advertiser, Jan. 8, 1802, p. 3. "Congress. House of Representatives. Orleans Territory," National Intelligencer and Washington Advertiser, Jan. 10, 1811, p. 3.

${ }^{4}$ Rebecca J. Scott and Jean M. Hébrard, "Rosalie of the Poulard Nation: Freedom, Law, and Dignity in the Era of the Haitian Revolution," in Assumed Identities: The Meanings of Race in the Atlantic World, ed. John D. Garrigus and Christopher Morris (Arlington, 2010), 116-43; Rebecca J. Scott and Jean M. Hébrard, "Servitude, liberté et citoyenneté dans le monde atlantique des XVIIIe et XIXe siècles: Rosalie de nation Poulard" (Slavery, freedom, and citizenship in the Atlantic world of the 18th and 19th centuries: Rosalie of the Poulard Nation), Revue de la Société haïtienne d'histoire et de géographie (Port-au-Prince), 83 (July-Sept. 2008), 1-52; Rebecca J. Scott and Jean M. Hébrard, Freedom Papers: An Atlantic Odyssey in the Age of Emancipation (Cambridge, Mass., 2012); Rebecca J. Scott, "Public Rights and Private Commerce: A Nineteenth-Century Atlantic Creole Itinerary," Current Anthropology, 48 (April 2007), 237-56; Rebecca J. Scott, "The Atlantic World and the Road to Plessy v. Ferguson," Journal of American History, 94 (Dec. 2007), 726-33. Martha Elizabeth Hodes, The Sea Captain's Wife: A True Story of Love, Race, and War in the Nineteenth Century (New York, 2006); Martha Elizabeth Hodes, "The Mercurial Nature and Abiding Power of Race: A Transnational Family Story," American Historical Review, 108 (Feb. 2003), $84-118$. Daniel L. Schafer, Anna Madgigine Jai Kingsley, African Princess, Florida Slave, Plantation Slaveowner (Gainesville, 2003).
} 
attention to the experiential horizon of individuals and small groups, and a focus on the range of possibilities available to individuals at a particular moment and over time, along with the conviction that social systems and norms are never fully integrated nor coherent. When these historians move from the particular to the general they do not contend that the cases they study are "representative" or "typical," and they do not predict that what is observed at the micro level (a family or a neighborhood) will necessarily resemble what is observed at the macro level (a region or a country, as is the case in Ira Berlin's work). Rather, they argue that testing the validity of broad concepts and categories on small units is both legitimate and meaningful. For instance, Hodes looks at the ways racial categories such as white, black, and mulatto were used in different contexts over the lives of two individuals, and she is able to draw conclusions about "the mercurial nature and enduring power of race." The micro-historical study I propose here is similar in its approach to the work of Scott and Hébrard. Like theirs, it focuses on individual Atlantic creole trajectories and has required painstaking archival and genealogical research in more than one location (in the case of this study, Louisiana, southwestern France, Spain, and Cuba). It goes further than theirs in being more explicitly a work of historical anthropology, focusing on matrimonial strategies as well as strategies of asset transmission, with the assumption that these strategies are points of contact between the individual and the social: birth, marriage, and death records, wills, property transaction records, records of the sale or manumission of slaves, when examined carefully and compared over several generations, give us a glimpse of how individual and group identities as well as a person's position in the social hierarchy were constantly renegotiated.Additionally, bycomparing two families, one "black" and one "white," this study shows that negotiations regarding individual identity took place in very similar ways across what we now understand as the color lines. This Atlantic story starts with an 1813 New Orleans civil case in which the defendant was white and the plaintiff a free man of color. I study and compare the family histories of both parties, going back to the early eighteenth century and moving forward to the late nineteenth century. ${ }^{5}$

\section{A Free Man of Color Goes to Court}

The New Orleans Parish Court was established in 1813, shortly after Louisiana became a state. One of the first cases tried there was a dispute between a defendant named Charles Lamerenx and a plaintiff named Charles Decoudreau, who represented the estate of his mother, Fanchonette Decoudreau. The court records designate Charles Decoudreau and his mother, respectively, as a "free man of color" and a "free woman of color." The dispute began two years earlier. On February 11, 1811, Charles Decoudreau, on behalf of his mother's estate, sold a house to Lamerenx (who was named without a color designation and therefore assumed to be white). The house was located on Bayou Saint John Road, on the left side of the road as one leaves New Orleans, not far from the city limits. For the house and two arpents of land (1.69 acres), Lamerenx agreed to pay \$3,660 (approximately $\$ 47,000$ in 2012 dollars). He paid $\$ 500$ in cash and signed two promissory notes, one

5 Jacques Revel, ed., Jeux d'échelles. La micro-analyse à l'expérience (Scaling up and down. Experiments in microanalysis) (Paris, 1996), 7-36; Maurizio Gribaudi, Itinéraires ouvriers: Espaces et groupes sociaux à Turin au début du XXe siècle (Working-class itineraries: Social groups and spaces in Turin at the turn of the early 20th century) (Paris, 1987). Hodes, "Mercurial Nature and Abiding Power of Race." 


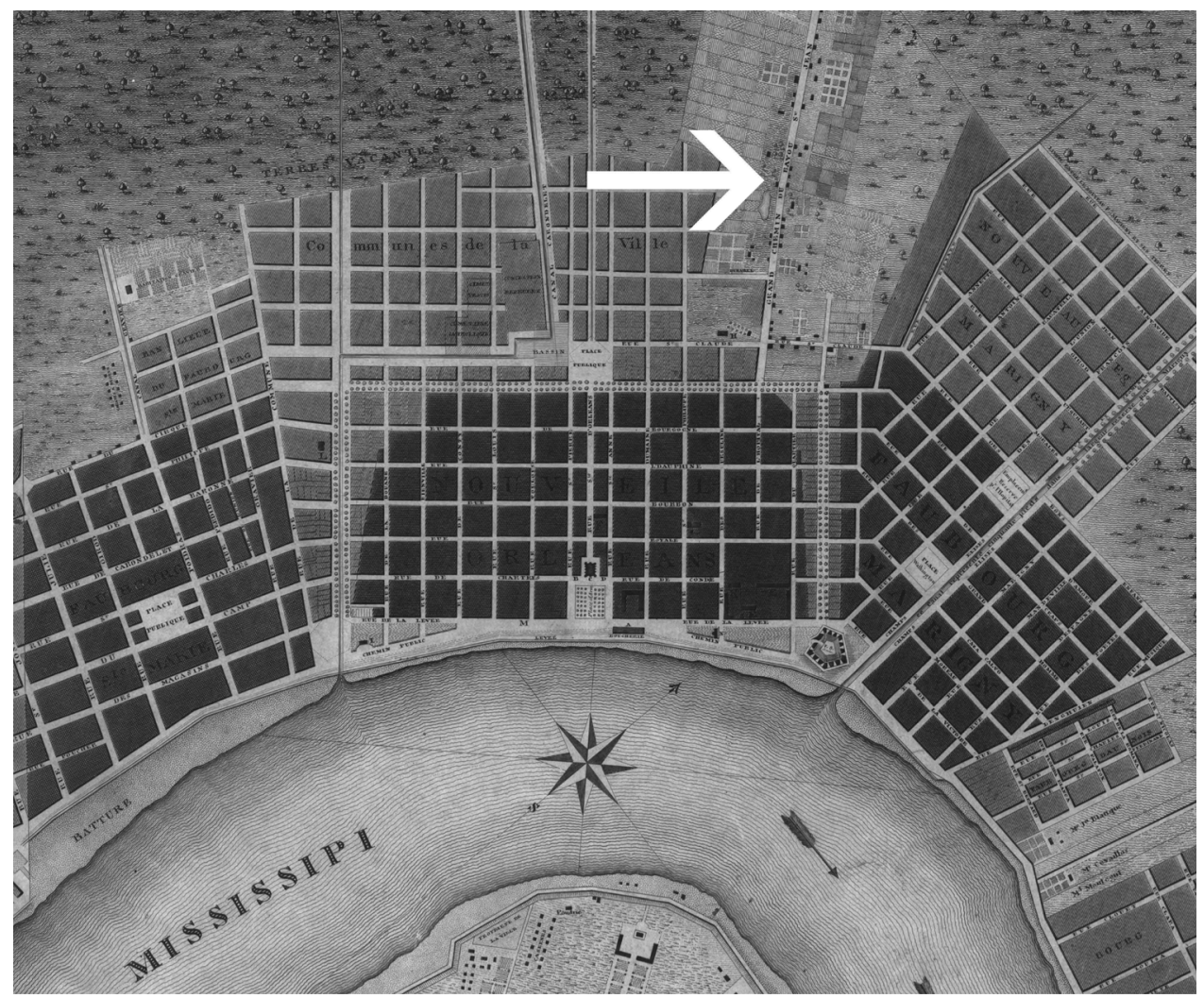

Figure 1. This map is a detail from the "Plan of the City and Suburbs of New Orleans: From an Actual Survey Made in 1815," by Jacques Tanesse, city surveyor. The arrow, which is not part of the original map, indicates the location of the Decoudreau house on Bayou Road. Full map may be viewed at American Memory: Library of Congress, http://memory.loc.gov/cgi-bin/query/h?ammem/gmd :@field\%28NUMBER+@band\%28g4014n+ct000684\%29\%29. Courtesy Library of Congress, Geography and Map Division.

with a one-year term and the other with a two-year term, guaranteed by a mortgage on the house. $^{6}$

The map of New Orleans and its suburbs made by Jacques Tanesse in 1815 shows that the area was sparsely populated and that the houses were lined up on the edge of the road. (See figures 1 and 2.) Remarkably, we have a picture of this particular house as it looked in 1849, thanks to the New Orleans Plan Book, which contains watercolor illustrations of properties for sale. (See figure 3.) The house does not seem to have been altered between 1811 and 1849, showing no extensions or additions. New Orleans architectural historians refer to this type of house as a four-bay "Creole cottage," typical of the faubourgs (suburbs) and suitable for two families. This type of building was common throughout French and Spanish America in the eighteenth century: Roulhac Toledano has asserted that it was brought to New Orleans by migrants from other Spanish colonies and by French refugees

${ }^{6}$ Estate of Françoise Dubrauil, alias Franchonette Decoudreau, vs. Charles Lamerenx (1813), 020-187, Orleans Parish, Parish Court Records (New Orleans Public Library, La.). I have translated into English quotations from French sources. 


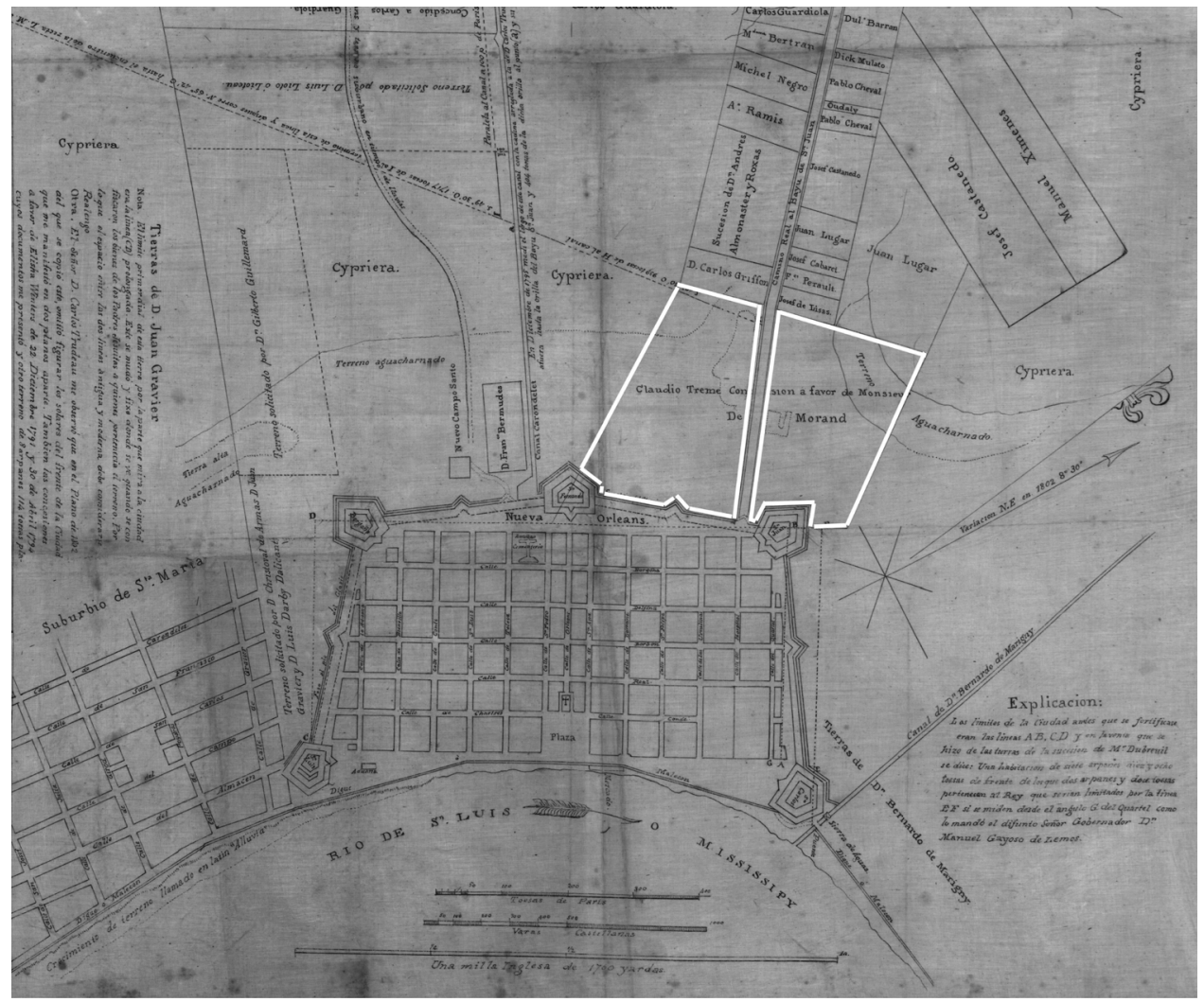

Figure 2. This map shows New Orleans in 1804. It is a detail of an 1873 copy of an 1804 map, copied by Vincente Sebastián Pintado in 1819, that reflects information compiled by Pintado in 1795-1796 and set down by Carlos Trudeau, surveyor general. The Tremé concession (the boundaries of which are highlighted by white lines added for this article) is indicated as having been previously owned by Charles de Morand. Full map may be viewed at American Memory: Library of Congress, http://memory.loc.gov/cgi-bin/query/h?ammem/gmd:@field\%28NUMBER+@band\%28g4014n+ lh000959\%29\%29. Courtesy Library of Congress, Geography and Map Division.

from Saint Domingue who fled the Haitian Revolution (1791-1804). The Decoudreaus had purchased the land just three years before from Claude Tremé, who owned the entire area (see figure 2) now referred to as Faubourg Tremé, recently made famous by an Hво television series and an earlier television documentary, Faubourg Tremé: The Untold Story of Black New Orleans. ${ }^{7}$

7 "Plan of the City and Suburbs of New Orleans, from an Actual Survey Made in 1815 by F. Tanesse, City Surveyor," 1817, map, digital ID g4014n ct000684 (Geography and Map Division, Library of Congress, Washington, D.C.), http://hdl.loc.gov/loc.gmd/g4014n.ct000684. In the 1811 New Orleans directory, Charles Decoudreau's house is identified as the nineteenth house on Bayou Road. See Whitney's New Orleans Directory and Louisiana \& Mississippi Almanac for the Year 1811 (New Orleans, 1810). The New Orleans Plan Book is a collection of 5,149 large-scale watercolor lot surveys that range from 1803 to 1918, which often included architectural drawings and landscape designs. The collection is held by the New Orleans Notarial Archives Research Center, La. Roulhac B. Toledano, A Pattern Book of New Orleans Architecture (Gretna, 2010), 71, 68; Roulhac Toledano and Marie Louise-Christovich, New Orleans Architecture, vol. VI: Faubourg Tremé and the Bayou Road (Gretna, 1980), 145. Sale from Claude Tremé to Françoise Dubreuil (also referred to as Fanchonette Decoudreau), July 26, 1808, Pierre Pedescleaux, notary public, vol. 57, p. 290 (New Orleans Notarial Archives Research Center). Treme, ex. prod. David 


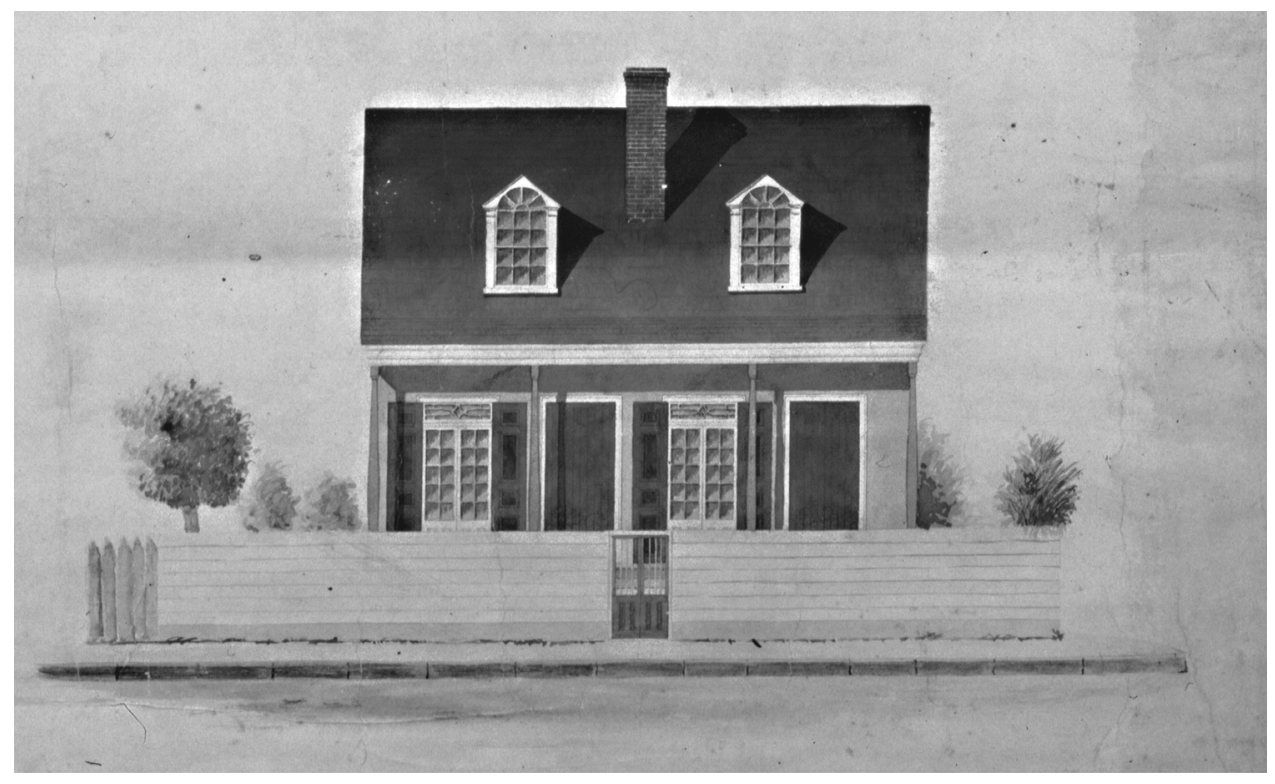

Figure 3. The Decoudreau house, shown here, was built between 1808 and 1810 by Charles Decoudreau, a free man of color, for his mother, Fanchonette Decoudreau. This is a detail of a watercolor by Eugène Surgi made for a sale in 1849. Reprinted from Plan of a valuable property in Municipality No. 1. New Orleans Plan Book 36, folio 5. Courtesy New Orleans Notarial Archives.

Charles Lamerenx failed to make the promised payments on the notes. On February 9, 1813, Marc Lafitte, notary public for the parish of New Orleans, went to the Bayou Road house to notify Lamerenx of his delinquency. Lamerenx was not there. His neighbors said that he had left town and was "sailing." Lamerenx being still absent and delinquent, on July 14, 1813, the parish court judge ordered the seizure of the house to settle an outstanding debt of $\$ 2,559 .^{8}$

\section{From America to Europe: Charles Lamerenx}

Where in the world was Charles Lamerenx? For an answer to this question, we must turn to the Spanish and Cuban archives. On April 7, 1817, Lamerenx, jailed in Cadiz, Spain, and about to be transferred to the Spanish presidio of Ceuta on the northern coast of Africa, wrote a lengthy petition to the king of Spain to explain his situation and ask for clemency. Lamerenx recounted that he had departed New Orleans (most likely in late 1811) to attend to some business in Cartagena (a city on the Atlantic coast of present-day Colombia). Because there was no regular ship headed back to New Orleans when he finished, he reluctantly boarded the privateer schooner La Belona. On the way, the privateer

Simon et al. (нво, April 11, 2010- ); Faubourg Tremé: The Untold Story of Black New Orleans, dir. Dawn Logsdon (Serendipity Films, 2008).

8 Estate of Françoise Dubrauil, alias Franchonette Decoudreau, vs. Charles Lamerenx (1813), 020-187, Orleans Parish, Parish Court Records. 
captured the Spanish brigantine Cupido with its entire crew and passengers. Lamerenx insisted to the king that he had nothing to do with that act of piracy and never profited from it. He had pleaded with the privateer captain for a humane treatment of the prisoners and even helped the captives with his own money. Lamerenx disembarked in Jamaica. Still unable to make his way back to New Orleans, he found a ship that took him to Trinidad and eventually to the city of Matanzas, Cuba, where he had relatives. In the meantime, the Spanish prisoners from the Cupido had been freed and had arrived in Cuba. They recognized Lamerenx and denounced him as a pirate. He was tried by a Spanish court and sentenced to ten years of hard labor in a penitentiary in Africa (according to a 1771 Spanish law, hard labor in Africa was the punishment for crimes committed with "a depraved and wicked mind"). Lamerenx was doubly guilty in the eyes of the Spanish. Not only had the privateer captured a Spanish vessel but La Belona flew an insurgent flag as well: Cartagena was a rebel city that had declared its independence from Spain in 1811. Lamerenx was a pirate and a traitor.'

We know that Lamerenx's earlier pleas for clemency were turned down, and there is no record of an official reply to his petition to the king. Maybe he was released. Maybe he escaped. In any case, less than a year later Lamerenx was no longer in Africa but in France, where he sued his sister to take control of his parents' estate and sold about half of it to support himself. In 1818 he sold a town house and two farms he owned in La Bastide Clairence, a town of approximately two thousand inhabitants in the Basses-Pyrénées in southwest France. Lamerenx received 4,000 francs from this transaction (approximately $\$ 10,500$ in 2012 dollars) and tried to live off the rest of his estate, located near the town of Saint-Palais (also in the Basses-Pyrénées). However, the farmland produced little, and the estate was burdened with large debts. In 1828 Lamerenx, fifty-three years old and single, transferred the property back to his sister and moved in with Madeleine Biscay, a twentyyear-old seamstress who was the daughter of a local farmer. ${ }^{10}$

Being officially without property, Lamerenx was able to seek government support. Restoration France was not exactly a welfare state, but Lamerenx belonged to a category of citizens eligible for help. We learn this from a letter he sent on November 20, 1829, to the French minister of the Interior. In it he declares he is a refugee from Saint Domingue. "I was born to enjoy a good fortune," he writes, "but the fateful revolution of the island of Saint Domingue destroyed all my hopes." He continues: "Having survived the massacres perpetrated by the Negroes, I thought I could find support in the estate of my ancestors, but the infidelity or the incompetence of those agents who were entrusted with it was such that the debts outweighed the money I was owed and could not collect. I therefore have no choice but to humbly solicit the annual support granted by the King's munificence to

\footnotetext{
9 Carlos de Lamerenx Duhart to the King of Spain, April 7, 1817, folder 155, file n51, Ultramar (General Archives of the Indies, Seville, Spain); "Asuntos políticos: Cuaderno de los autos contra D. Carlos Lamerens por infidencia” (Political affairs: Record of the proceedings against Don Carlos Lamerens for treason), Aug. 13, 1815, file 15, no. 36 (National Archives of Cuba, Havana). Ignatius Jordan de Asso y del Río and Miguel de Manuel y Rodriguez, Institutes of the Civil Law of Spain, trans. Lewis F. C. Johnston (London, 1825), 283.

${ }_{10}$ Charles Lamerenx was sentenced on December 4, 1815, by the Real Audiencia (an appeals court) of the island of Cuba after being exonerated by a lower court. See folder 28, file n3, folio 52n (General Archives of the Indies). An appeal was rejected on February 9, 1816. See folder 98, file n5, folio 19v. Charles Lamerenx v. Marguerite Laborde, née Lamerenx, 3 U 5 190, May 5, 1818 (Archives of the Pyrénées-Atlantiques Department, Pau, France). Sale from Charles Lamerenx and his coheirs to Jacob Gomès, transcribed at Mortgage Bureau of Bayonne, June 29, 1818, Pierre Damborgez, notary public, 321 Q 35, ibid. Biscay (Magdeleine) veuve Lamerens Duhart, colon réfugié de Saint-Domingue file, F/12/2751 (National Archives of France, Paris).
} 
those who survived the events." Lamerenx was granted a stipend of 300 francs per year (roughly \$1,100 in 2012 dollars). Every six months, the mayor of his place of residence had to certify that he was without resources. A few years later Lamerenx wrote again to ask for a raise. The stipend was increased to 480 francs, because of his age. ${ }^{11}$

Lamerenx's initial petition was supported by the testimony of his neighbors in SaintPalais who swore that he was the son of Jean-Pierre Lamerenx, born in France and deceased in Cuba around 1810. Jean-Pierre Lamerenx was the owner of a coffee plantation located in Le Dondon, in the northern part of Saint Domingue. In fact, this information, and much more, had already been provided by Lamerenx to another branch of the French bureaucracy. Support for the former colonists came in two separate ways. The Ministry of the Interior provided a modest annual stipend to families in need, and the Ministry of Finance had set up a commission to distribute the proceeds from the large indemnity the Haitian government had agreed to pay in exchange for the formal recognition of Haitian independence by Charles $\mathrm{X}$ in 1825 . Because of a legal requirement that this distribution should be made public, the Finance Ministry printed a six-volume list of former property owners, the location of their property, its value, and the share of the value to be distributed to living heirs. From this document we learn that Jean-Pierre Lamerenx was indeed the owner of a coffee plantation located in the Matador neighborhood of Le Dondon parish. The amount paid from the indemnity fund was 15,275 francs (approximately \$58,000 in 2012 dollars), to be shared equally among the four living heirs. Since the indemnity was intended to cover about 10 percent of the value of lost property (which included the value of slaves), we can calculate that the Lamerenx estate in Saint Domingue had been worth approximately $\$ 580,000 .^{12}$

Knowing more about the background of Charles Lamerenx, we can safely assume that he did not feel any culture shock when he arrived in New Orleans from Cuba sometime in 1810. He seems to have left voluntarily, unlike the thousands of Saint Domingue refugees who were expelled from Cuba and sought refuge in New Orleans in 1809, following the invasion of Spain by Napoleon Bonaparte's troops. The "creole cottage" he purchased from Charles Decoudreau was much more modest than the plantation house he had owned in Saint Domingue, but this type of building was familiar to anyone who had lived in Saint Domingue or Cuba. Historians have noted that eighteenth-century Saint Domingue and colonial New Orleans had similar social structures: a large African slave population (proportionally larger in Saint Domingue than in New Orleans), a group of whites who owned large estates and were often noble, a group of white artisans and merchants of humbler means and extraction, and the gens de couleur libres (free people of color) - a group of African and mixed-race artisans and property owners who were often quite prosperous

11 Charles Lamerenx to Minister of the Interior, Nov. 20, 1829, Biscay (Magdeleine) veuve Lamerens Duhart, colon réfugié de Saint-Domingue file, F/12/2751 (National Archives of France).

12 Ibid. Christiane Demeulenaere-Douyère, "L'Etat 'réparateur' des accidents de l'Histoire: L'exemple des secours aux colons spoliés" (The state as "compensator" for accidents of history: The case of pensions for expropriated colonists), Revue Administrative (Paris), special issue (2007), 74-84. Etat détaillé des liquidations opérées à l'époque du 1er janvier 1828-1832 et les six premiers mois de 1833, par la Commission chargée de répartir l'indemnité attribuée aux anciens colons de Saint-Domingue, en exécution de la loi du 30 avril 1826 et conformément aux dispositions de l'ordonnance du 9 mai suivant (Detailed status of liquidations performed from January 1, 1828-1832, and the first six months of 1833 , by the committee in charge of allocating the indemnity intended for the former colonists of Saint Domingue, in execution of the law of April 30, 1826, and in accordance with the stipulations of the decree of May 9 of the same year) (6 vols., Paris, 1828-1833), III, 82-83. 
and were slave owners themselves. This tripartite system (comprising whites, blacks, and free-coloreds) was unusual in the Atlantic world. Its existence has been ascribed to cultural differences between Protestants who saw the world in black and white, and Catholics who were more accepting of race mixing (incidentally, this is the explanation given by interviewees in the documentary Faubourg Tremé for the presence of free people of color in New Orleans). However, this culturalist interpretation cannot account for the social structure of Brazil, a Catholic country that had a two-tiered system in which mixed-race property owners were recategorized as white, just as in Protestant, English-speaking Jamaica, or in South Carolina. The concept of "mulatto" was ubiquitous in the Atlantic world, but in Saint Domingue (and later in New Orleans) gens de couleur were increasingly treated as a legally separate group defined by blood, while in eighteenth-century Brazil, Jamaica, or South Carolina, the definition of whiteness was mostly a social one and tied to the size of one's property holdings. ${ }^{13}$

Charles Lamerenx (1775-1854) was white and belonged to minor nobility, as many French plantation owners did. His full name was Charles Lamerenx d'Uhart-Juson. His family's presence in Saint Domingue had started two generations before him. His greatuncle Marc-Antoine Lamerenx emigrated to Saint Domingue in 1728 at the age of eighteen and was one of the early settlers and first coffee growers of Le Dondon. It was in Le Dondon that the first coffee plantations were established in Saint Domingue in the late 1730s. This was followed by spectacular growth in the industry: on the eve of the French Revolution, Saint Domingue produced 60 percent of the world's coffee. As compared with sugar plantations, coffee plantations required a much smaller investment in plant and equipment and could be run profitably with fewer slaves. Working conditions in coffee plantations were somewhat less dire than they were in sugar plantations. Marc-Antoine's widow, Elizabeth Le Jeune ("la dame Duhart"), was still the owner of the plantation when Moreau de Saint-Méry wrote his description of the island of Saint Domingue in 1789. Charles's father, Jean-Pierre, born in La Bastide Clairence, France, sailed from Bayonne to CapFrançais (now Cap-Haïtien) on La Marianne in September 1764 at the age of twenty-two and settled in Le Dondon, where he established a coffee plantation with the support of his uncle Marc-Antoine. Jean-Pierre's eldest son, Charles Lamerenx, born in Le Dondon on October 10, 1775, was set to inherit the family plantation and have a predictably comfortable life. Starting in 1791, just about every event in his life was something he could not have imagined. ${ }^{14}$

${ }^{13}$ Laura Foner, "The Free People of Color in Louisiana and St. Domingue: A Comparative Portrait of Two Three-Caste Slave Societies," Journal of Social History, 3 (Summer 1970), 406-30; Stewart R. King, Blue Coat or Powdered Wig: Free People of Color in Pre-revolutionary Saint Domingue (Athens, Ga., 2001), 3-80; Nathalie Dessens, From Saint-Domingue to New Orleans: Migration and Influences (Gainesville, 2007), 6-45, 91-108. Frank Tannenbaum, Slave and Citizen: The Negro in the Americas (New York, 1947). John D. Garrigus, Before Haiti: Race and Citizenship in French Saint-Domingue (New York, 2006), 1-19. Joel Williamson, New People: Miscegenation and Mulattoes in the United States (Baton Rouge, 1995), 17-20, 18.

${ }_{14}$ Moreau de Saint-Méry, Description de la partie française de l'île de Saint-Domingue (Description of the French part of the island of Saint Domingue) (2 vols., Paris, 1958), I, 255. This work was originally published in Philadelphia in 1797. Marc-Antoine Lamerenx had his nobility certified by France's official genealogist, Pierre d'Hozier, in 1770. See Nouveau d'Hozier Collection, 201-4482 (National Library of France, Paris); and Chérin Collection, 1152381, ibid. Papers of the Darrieux-Juson family, courtesy of Denis Dufourcq, La Bastide Clairence, France. Jacques de Cauna, L'Eldorado des Aquitains. Gascons, Basques, et Béarnais aux Iles d'Amérique (XVIIe-XVIIIe siècles) (The Eldorado of the Aquitanians. Gascons, Basques, and Béarnais in the islands of America [17th-18th centuries]) (Biarritz, 1998), 19, 222-27. 


\section{From Africa and Europe to America: The Decoudreau Family}

Charles Decoudreau (1772-1846), a carpenter by trade, is designated in the records of his dispute with Lamerenx as homme de couleur libre (free man of color). This French term, which had no equivalent in Spanish, became mandatory in notarial records a few years after the Louisiana Purchase and gathered in one category all mixed-race individuals who were free. His mother, Fanchonette Decoudreau, is designated in eighteenth-century Spanish notarial records as mulata libre (free mulatress). Charles was a "quadroon" in the racial parlance of the time, meaning that his ancestry was one-quarter African and threequarters European. He married another quadroon, Margarita Castañedo, a native of Cuba, in 1798. The position of gens de couleur in the social hierarchy was a complicated one. The emergence of this group as an endogamous caste was a relatively late phenomenon. Eighteenth-century French and Spanish legal norms prohibited racial mixing, but these rules were routinely circumvented. Unions between white men and black women (slave or free) were frequent, and significant transfers of wealth occurred from white fathers to their black partners and their mixed-race children. Why exactly a three-caste system emerged in New Orleans and Saint Domingue is not totally clear. The historian John D. Garrigus, who has studied Saint Domingue, interprets the system as being the result of an alliance between poor and wealthy whites to exclude free-coloreds from the ruling class. According to the historian Paul F. Lachance, who has worked on New Orleans, the causes include a change in racial and sex ratios (more white women became available as potential spouses in the nineteenth century), the racial endogamy of Anglo-Americans who moved to New Orleans after the Louisiana Purchase, and calculations of the free-coloreds themselves, who, instead of producing illegitimate children with whites, preferred to produce legitimate children by marrying within their own group. Jennifer M. Spear, who has done historical work on New Orleans as well, interprets the phenomenon as the result of a compromise between an Anglo-American binary racial system and the more fluid system of Spanish New Orleans. What is clear, however, is that in both Saint Domingue and New Orleans, the intermediate category of gens de couleur was codified in law and custom only gradually. In the case of New Orleans, endogamy within the free-colored group did not become an absolute rule until the 1840 s. $^{15}$

The early history of these New Orleans mixed-race families is sometimes difficult to trace, especially on the paternal side. Out-of-wedlock filiations were probably common knowledge among contemporaries, and a large number of white fathers recognized their mixed-race offspring in their wills, but fathers are not always named in the written records. There are several mentions of a French officer named Charles Renard des Coudreaux in Louisiana in the 1770s, who was most probably Charles Decoudreau's father, but no

15 Jennifer M. Spear, Race, Sex, and Social Order in Early New Orleans (Baltimore, 2009), 190, 178-214. On gens de couleur in New Orleans, see ibid.; Shirley Elizabeth Thompson, Exiles at Home: The Struggle to Become American in Creole New Orleans (Cambridge, Mass., 2009); Sybil Kein, ed., Creole: The History and Legacy of Louisiana's Free People of Color (Baton Rouge, 2000); Kimberly S. Hanger, Bounded Lives, Bounded Places: Free Black Society in Colonial New Orleans, 1769-1803 (Durham, N.C., 1997); Caryn Cossé Bell, Revolution, Romanticism, and the Afro-Creole Protest Tradition in Louisiana, 1718-1868 (Baton Rouge, 1997); and Foner, "Free People of Color in Louisiana and St. Domingue," 406-30. Garrigus, Before Haiti, 141-70. Paul F. Lachance, "The Formation of a Three-Caste Society: Evidence from Wills in Antebellum New Orleans," Social Science History, 18 (Summer 1994), $211-42,223$. 
written record shows this. There is written evidence, however, of Charles Decoudreau's ancestry on his mother's side. ${ }^{16}$

Shortly before she died in 1810, Charles's mother, Fanchonette, dictated her last will to Pierre Pedescleaux, notary public of the city of New Orleans. In it she declares that she is "Françoise Dubreuil, native of the City of New Orleans, natural daughter of Nanette Dubreuil, free woman of color, and of Monsieur Dubreuil." Who are Monsieur Dubreuil and his colored partner Nanette? It turns out that this couple is known to the New Orleans historians Virginia Meacham Gould and Emily Clark, who studied the ascendancy of Henriette Delille (1812-1862), the free creole woman of African descent who founded the Sisters of the Holy Family, a Roman Catholic order. "Monsieur Dubreuil" was Claude Joseph Dubreuil (1693-1757), a native of Dijon, France, who sailed with his wife and two children from La Rochelle to Louisiana in 1718 on Le Comte de Toulouse and settled next to Jean-Baptiste de Bienville, the founder of New Orleans. Dubreuil was a wealthy planter and contractor who established the city's first levees and canal system. In the mid-1700s he owned more than five hundred slaves, which made him the largest slave owner in New Orleans. Nanette was a slave in the Dubreuil household. According to Gould and Clark, she was most likely from Senegambia in western Africa and a member of the coastal Wolof ethnic group. The Wolof were accustomed to contacts with Europeans and therefore considered best suited to serve as household slaves. French was spoken in parts of the coast of Senegal, as well as a French pidgin that may be the ancestor of all French creole languages. Nanette was probably brought to New Orleans in 1720, when she was approximately ten years old. She may have been chosen as a household slave because she already had some knowledge of the French language. She had five children with Dubreuil, including Fanchonette, who was born in 1737. Nanette was an active member of the St. Louis Catholic parish of New Orleans and is recorded as godmother for the baptism of several slaves. She purchased her freedom from Claude Joseph Dubreuil's son in 1763. It is not clear when her daughter Fanchonette won her freedom, but she appears as a mulata libre in notarial records from the 1780s and 1790s. Like many free women of color in New Orleans and Saint Domingue, Fanchonette accumulated significant wealth over the course of her life, thanks to her own industry and to the protection of her white partner (in all likelihood the French officer Charles des Coudreaux, as we have seen above). Upon her death in 1810 , her estate was valued at $\$ 6,480$ (about $\$ 88,000$ in 2012 currency). This included a house at the corner of Dauphine and Ursulines (valued at $\$ 2,500$ in 1810), the house on Bayou Road that was later purchased by Charles Lamerenx $(\$ 2,500)$, a plot of land on Bayou Road (\$400), a thirty-year-old slave woman of the Mandingo nation named Louise (\$400), and a forty-year-old male slave named Antoine, also a Mandingo (\$550). In addition, a mulatto slave named François was freed upon Fanchonette's death as a reward for taking care of her in her illness. ${ }^{17}$

16 A Carlos Descoudreaux was appointed lieutenant colonel of infantry by the king of Spain. See Mercurio Historico (Madrid), 30 (Oct. 1777), 172. The same officer served as commandant of the Iberville district, 1771-1774. A full ensign at Natchez in 1758, he was characterized by Louis Billouart, Chevalier de Kerlérec, the French governor of Louisiana, as "enthusiastic" and "well-behaved." See "Descoudreaux, Charles," in France's Forgotten Legion: Service Records of French Military and Administrative Personnel Stationed in the Mississippi Valley and Gulf Coast Region, 1699-1769, by Carl A. Brasseaux (CD-ROM, Baton Rouge, 2000). Will of Françoise Dubreuil, Sept. 4, 1810, Pierre Pedescleaux, Notary Public, Will Book, vol. 1, pp. 322-25 (New Orleans Notarial Archives Research Center).

17 Emily Clark and Virginia Meacham Gould, "The Feminine Face of Afro-Catholicism in New Orleans, 1727 1852," William and Mary Quarterly, 59 (April 2002), 409-48, esp. 420, 429-30; Virginia Meacham Gould, "AfroCreole Women, Freedom, and Property-Holding in New Orleans," in Coastal Encounters: The Transformation of the 
It seems difficult to reconcile the trajectory of Nanette and her children with the familiar picture of plantation slaves as rootless, helpless, and destitute. Also, it is not immediately clear how Nanette's family could have moved from slavery to moderate wealth in two generations. Our image of slavery is informed by our knowledge of the large-scale plantation system of the nineteenth century, in which manumission was rare, if not impossible, and an essential connection was assumed between servitude and race. Berlin's concept of "Atlantic creole" allows us to understand the status of Nanette and her children as more akin to that in the slavery systems of the ancient Mediterranean world or early modern Africa. Those systems did not necessarily involve less brutality than the later regime, but they did not assume an incommensurable distance between master and slave and allowed for frequent manumissions. ${ }^{18}$ A sense of the status of free women of color in New Orleans and Saint Domingue may be best conveyed through an eighteenth-century drawing by Agostino Brunias (see cover), which gives us an idea of what Fanchonette may have looked like when she was a young woman: free-colored women were known for their distinctive hairstyle and their luxurious dress, which was a display of their economic power. (See cover.)

Clark and Gould observe that Nanette's relationship with Dubreuil was consistent with Wolof polygamous traditions (Dubreuil had one white and one black family). One may argue that for Nanette and her daughters, the model was not African polygamy but something much more culturally and geographically specific. In the French trading posts of Gorée and Saint-Louis, a group of mixed-raced women, the signares had quasi-marriages (mariages à la mode du pays) with French officers and traders. The signares were Catholic and spoke French. They sought partnerships with men who had wealth and power. The offspring of these unions often married the children of other signares to maximize wealth accumulation within the group. Figure 4 is a picture of a signare that dates from the 1790 s, while the picture of Saint Domingue women of color (cover image) dates from the 1760s. Both pictures convey a conspicuous display of wealth and a sense of power and economic independence. More generally, there are remarkable parallels between the Senegalese signares and the New Orleans placées (or the Saint Domingue ménagères). A placée would enter into a long-term relationship with a wealthy white man. In exchange for companionship and sexual favors, the placée was usually given the ownership of a house and funds for the education of her children, who were often also recognized in their father's will. Charles Decoudreau's sister Françoise was the placée of a wealthy white man, Louis Dauquemenil de Morand. When Louis de Morand dictated his last will on his deathbed in 1821, the notary recorded that he was living in a house that was the sole property of his concubine Françoise. Because Louis had a legitimate son from an earlier marriage (who would receive four-fifths of the estate), the three illegitimate daughters he had with Françoise had to share one-fifth of the estate. When the testator was not married and had no siblings,

Gulf South in the Eighteenth Century, ed. Richmond F. Brown (Lincoln, 2007), 151-66. "Rôle des passagers embarqués pour la Louisiane" (Roll of passengers embarked for Louisiana), Nov. 15, 1718, La Rochelle, G1 464 n6 (National Overseas Archives, Aix-en-Provence, France); Census of New Orleans, 1724, COL G1 464, ibid. John H. McWhorter, The Missing Spanish Creoles: Recovering the Birth of Plantation Contact Languages (Berkeley, 2000), 146-91. Pedro Pedesclaux, notary public, "Index January-April 1799,” p. 5 (New Orleans Notarial Archives Research Center), http://www.notarialarchives.org/ppindices/ppVol33Index.pdf. Probate inventory of Françoise Dubreuil, aka Fanchonette Ducoudreau, Dec. 26, 1810, letter "D," Will Book, vol. 1, p. 322, Court of Probates (Orleans Parish) General Index of All Successions, 1805-1846 (New Orleans Public Library). Will of Dubreuil.

${ }^{18}$ Keith Hopkins, Conquerors and Slaves: Sociological Studies in Roman History (Cambridge, Eng., 1978). 


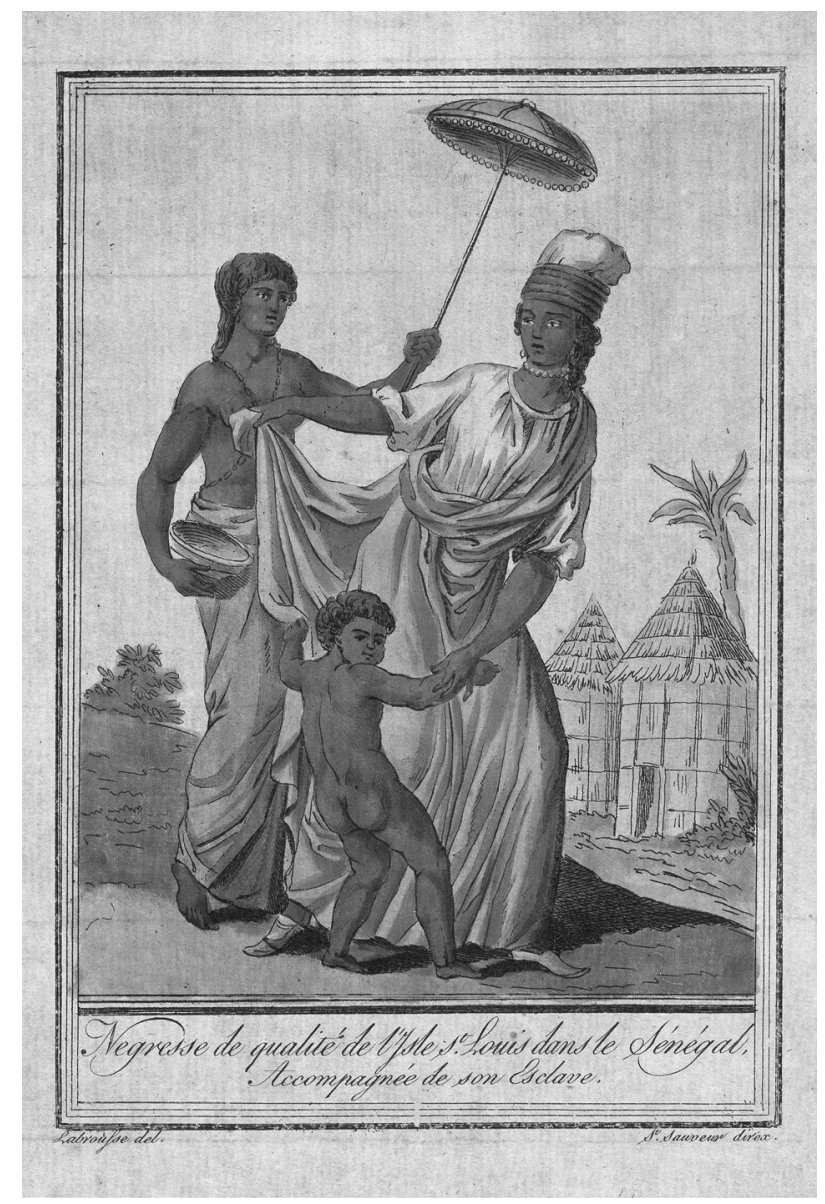

Figure 4. This 1796 etching, A distinguished Negress from the island of St. Louis in Senegal, accompanied by her slave, was made by Jacques Grasset de Saint-Sauveur (1757-1810). Signares owned household slaves as a symbol of status. (ORMNGrand Palais/Jean-Gilles Berizzi. Courtesy Réunion des Musées Nationaux via Art Resource.

transfers to free-colored children could be more generous. Charles Decoudreau's son-inlaw, Paul Trévigne, was the illegitimate son of a wealthy white man, Joseph Trévigne, and a free-colored woman, Marguerite Meunier. Because the white man had never been married and had no immediate white relatives, Paul Trévigne inherited his father's entire estate in 1828. If we look at the matrimonial strategies of Nanette and her descendants, we get a sense of individual variations within a range of available choices, and we also see how available choices changed over time. Nanette, born on the coast of Senegal, was the concubine of the wealthiest man in New Orleans, in a fashion reminiscent of Senegalese signares. Each of her four daughters, including Fanchonette, had a long-term relationship with a white military officer. Her son married a free woman of color. Fanchonette had two daughters and a son. The son, Charles, married a free woman of color. A daughter, Marguerite, married a free man of color. The other daughter, Françoise, was the concubine of 
a wealthy white man. Charles had seven children with his wife, Margarita: all those for whom we have records married within the free-colored group. ${ }^{19}$

Thanks to notarial and census records we can situate Fanchonette in a family network of early property owners on Bayou Road. Fanchonette purchased the lot on the edge of Bayou Road in 1808 and asked her son Charles, who was a carpenter, to build a house on the lot. In 1810 the house was inhabited by Fanchonette, Charles, and his family. Fanchonette's oldest daughter, Marguerite (aka Pouponne), had purchased an adjacent lot in 1806. Another daughter of Fanchonette, Françoise Decoudreau, is mentioned in the 1810 U.S. census as living on the same stretch of Bayou Road. Françoise was the placée of Louis Dauquemenil de Morand, who was a son of Charles de Morand, the original owner of the concession that was later purchased by Claude Tremé and now bears Tremé's name, even though it was in his possession for just a decade. Charles de Morand had purchased the land directly from the French Company of the Indies in 1731. In other words, when Fanchonette bought the Bayou Road property, there had been only three owners before her since the original French settlement: the French Company of the Indies, Charles de Morand, and Claude Tremé. ${ }^{20}$

When Charles Decoudreau married Margarita Castañedo in 1798, one of the witnesses was Louis Dauquemenil de Morand. We can see that Fanchonette and her son Charles, both free persons of color and descendants of an African slave called Nanette, had intricate connections with the most powerful families in New Orleans. Charles was the grandson of Claude Dubreuil, one of the founders of the city, and Charles's quasi-brother-in-law, Louis Dauquemenil de Morand, was the son of a man who had owned most of the land north of the city. ${ }^{21}$ There is no doubt that the Decoudreaus saw themselves as belonging to a group of people who could trace their land ownership to the first French settlement in Louisiana.

Here too are parallels between New Orleans, Saint Domingue, and the French enclaves on the coast of Senegal. According to the historian George Brooks, "by 1749, ten of the thirteen private properties on Gorée belonged to Eurafricans, nine of whom were women." Stewart King's study of marriage contracts involving free-colored women in Saint Domingue shows that wives brought significantly greater assets to the marriage than did their husbands. In eighteenth-century New Orleans the vast majority of free-colored property owners were women. In Gorée as in New Orleans the children of free-colored women increasingly married within the free-colored group. As a result of this change, the balance of power between men and women shifted within the group. Before 1848, signares had on average five times the assets of their husbands. Yet by the end of the nineteenth century,

19 On the signares, see P. D. Boilat, Esquisses sénégalaises, physionomie du pays—peuplades—commerce—religionspassé et avenir-récits et légendes (Senegalese sketches, physiognomy of the country-populations-commercereligions-past and future-tales and legends) (Paris, 1853), 5, 212; and Jean-Luc Angrand, Céleste ou le temps des signares (Céleste or the time of signares) (Paris, 2006). Will of Louis Dauquemeny de Morand, March 30, 1821, letter "M," Will Book, vol. 3, p. 206, Court of Probates (Orleans Parish) General Index of All Successions (New Orleans Public Library). Will of Joseph Treviño, Oct. 2, 1828, letter “T,” Will Book, vol. 4, p. 204, ibid. Virginia Meacham Gould to Pierre Force, e-mail, Sept. 17, 2010 (in Pierre Force's possession).

${ }_{20}$ Sale from Claude Tremé to Fanchonette Decoudreau, July 26, 1808, Pedescleaux, notary public, vol. 57, p. 290 (New Orleans Notarial Archives Research Center). 1810 U.S. census, Orleans Parish, Louisiana, New Orleans, roll 10, p. 282, image 00244, available at Ancestry.com. Sale from Claude Tremé to Marguerite Decoudreau, Nov. 25, 1806, Pedescleaux, notary public, vol. 53, p. 828 (New Orleans Notarial Archives). Toledano and LouiseChristovich, New Orleans Architecture, 9-12. The ownership history of the property is recorded in sale from Claude Tremé and his wife to the Corporation of New Orleans, March 17, 1810, Michel de Armas, notary public, vol. 3, act no. 54 (New Orleans Notarial Archives).

21 Toledano and Louise-Christovich, New Orleans Architecture, 94, 9-12. 
the métisse (mixed-race) communities of Senegal were entirely ruled by men. A similar evolution took place in New Orleans. When Rodolphe Desdunes published Our People and Our History (1911), a series of biographical sketches of prominent New Orleans freecolored people of the nineteenth century, only four of the fifty biographies were of women. The issue of property rights was a central one in New Orleans as well as in the Senegal enclaves. As Brooks asserts, regarding Gorée and Saint-Louis, "The FrancoAfricans' support of British and French rule was further promoted by the introduction of European legal systems that secured their rights in regard to house plots and dwellings, ownership of slaves, and inheritance laws." Property rights were especially important for Senegalese signares and for New Orleans free-coloreds because, as intermediaries between groups, their own status was fragile and subject to constant renegotiation. This made ownership of land and slaves the single most important marker of their social status and identity, and their desire for land ownership often resulted in extreme geographic stability. As noticed by an interviewee in the Faubourg Tremé documentary, New Orleans gens de couleur had deep local roots, and many families lived in the same neighborhoods or even the same houses for several generations. After Charles Decoudreau sold his mother's house on Bayou Road to Charles Lamerenx, he moved less than a half mile away to Faubourg Marigny (at the corner of St. Anthony and Love), and his descendants stayed there for the better part of the nineteenth century. When the U.S. census was taken in 1850, Charles Decoudreau's son Joseph lived there with his wife and four children. Joseph Decoudreau is listed as carpenter like his father. The carpenter featured in the Faubourg Tremé documentary, Irving Trevigne, is a descendant of Charles Decoudreau. He says that both his father and grandfather were carpenters. ${ }^{22}$

Atlantic history usually focuses on trade and migration. It is important to notice that families such as the Decoudreaus had a very strong sense of local belonging, based on land transactions that went back to the early eighteenth century. Over the two centuries covered by this study, national and racial boundaries changed several times. Nanette's descendants were French, then Spanish, then briefly French again, then American. They were called mulatos and mulatas, then gens de couleur, then negroes, or whites, or creoles (the latter being what they most consistently called themselves). What remained constant was a sense of local belonging that was probably much stronger than any national or racial identity. As Desdunes wrote regarding Armand Lanusse (1812-1867), the most respected member of the antebellum New Orleans free-colored community: "Lanusse never boasted of being an American. His pride in being Creole was more dear to him than his being a Louisianan, or than anything else pertaining to his origin. All his preferences and resentments stemmed from this." 23

\section{Charles Lamerenx and the Haitian Revolution}

In his letters to the French authorities, Charles Lamerenx presented himself as a survivor of the massacres perpetrated by the slaves who rose against French rule. The conventional

22 Brooks, Eurafricans in Western Africa, 211, 259. King, Blue Coat or Powdered Wig, 197. Hanger, Bounded Lives, Bounded Places, 55-87. Angrand, Céleste ou le temps des signares, 159. Desdunes, Our People and Our History, 66-68. 1850 U.S. census, Orleans Parish, Louisiana, New Orleans Municipality 3, Ward 1, roll M432 238, p. 61A, image 126, available at Ancestry.com.

23 Desdunes, Our People and Our History, 21. 
story of the Haitian Revolution is that of a black-versus-white struggle: African slaves rose against their white masters and established the first independent black republic. Charles could be assumed to have sided with his own race in the struggle. What actually happened is more complicated. Lamerenx stated that he used to be a captain in the Légion de SaintDomingue, the French colonial militia. Because the militia was not a part of the regular French army, Lamerenx was not entitled to a military pension, a fact he denounced as unfair in view of his loyal service to the state and the wounds he received defending it. The exact military title Lamerenx gave himself in the correspondence was capitaine d'étatmajor. This very specific and unusual title referred to someone who served on the staff of a general officer. But for what general did Lamerenx work ? $^{24}$

One possible answer can be found in the memoirs of Isaac Louverture, Toussaint Louverture's son. Toussaint Louverture, the father of Haitian independence, led an army made up of former slaves as well as white soldiers and officers drawn from the remnants of ancien régime regiments. He initially sided with the Bourbon king of Spain against the regicide French republicans. His ostensible purpose, perceived at the time as similar to that of the Vendée insurrection (a royalist counterrevolt in France), was to defend the Bourbon dynasty and the Catholic Church as well as to free the slaves (the Spanish had promised freedom to the slaves who fought on their side, as Lord Dunmore, the British governor of Virginia, had done during the American Revolution). In 1794 Toussaint switched sides and put himself under the command of Gen. Etienne-Maynard Laveaux, commander of the French republican troops in Saint Domingue. In the meantime, the French civil commissioner Léger-Félicité Sonthonax had abolished slavery on the island. Toussaint's decision to switch sides was undoubtedly connected to this event, but the causal chain and Toussaint's "true" motives have been a matter of speculation. Sonthonax's decree, issued on August 29, 1793, was ratified by the French National Convention on February 4, 1794. Toussaint joined the French side in May 1794. In Isaac's account of his father's life, first published in 1825, a "Captain Lamérens" is mentioned as being on Toussaint Louverture's staff in 1794. This is corroborated by another mention of the same name in the unpublished part of Isaac's manuscript. Toussaint's decision to side with the French is narrated in the following way: "Followed by his aides-de-camp Birette, Dubuisson, Charles Belair and Lamérins, and by two officers of color, Lieutenant Colonel Dessalines and Captain Vène, who had escaped from Gonaïves, he departed from Marmelade, having decided to change the course of things and to deal with General Lavaux." 25

All the aides-de-camp mentioned here have been recorded by other nineteenth-century Haitian and French historians, except for "Lamérins." Isaac Louverture's narrative should

\footnotetext{
24 Biscay (Magdeleine) veuve Lamerens Duhart file, F/12/2751 (National Archives of France).

25 On Toussaint Louverture's white and mulatto entourage (mostly of southwestern French origin), see Jacques de Cauna, "La face cachée de Toussaint Louverture" (The hidden side of Toussaint Louverture), in Saint-Domingue espagnol et la révolution nègre d'Haïti (1790-1822) (Spanish Saint-Domingue and Haiti's black revolution [17901822]), ed. Alain Yacou (Paris, 2007), 295-321. On Louverture's motives to switch sides, see David Geggus, "From His Most Catholic Majesty to the Godless République: The 'Volte-Face' of Toussaint Louverture and the Ending of Slavery in Saint Domingue," Revue française d'histoire d'Outre-Mer (Paris), 65 (no. 241, 1978), 481-99. Isaac Louverture, Notes sur la vie de Toussaint-Louverture (Notes on the life of Toussaint-Louverture), in Histoire de l'expédition des Français, à Saint-Domingue (History of the French expedition in Saint-Domingue), by Antoine Métral (Paris, 1825), 334. Isaac Louverture, "Notes sur la vie de Toussaint-Louverture" (Notes on the life of Toussaint-Louverture), manuscript, NAF 12409, p. 57, file: Toussaint Louverture. Notes intéressantes sur Banica, etc. etc. L’entrée de Toussaint Louverture à Santo Domingo. Vallée de Constance (Toussaint Louverture. Interesting notes on Banica, etc. Toussaint Louverture's entry in Santo Domingo. Valley of Constance), (National Library of France).
} 
therefore be considered with caution. He seems to have worked almost exclusively from memory and oral tradition, and is not a very reliable source. It is also possible that the Lamerenx in question was not Charles but his father, Jean-Pierre, who commanded the French colonial militia for the Dondon region and took refuge in the Spanish part of Hispaniola in 1792. However, Toussaint's aides-de-camp were very young: Charles Lamerenx was only nineteen in 1794, but Charles Belair, another aide-de-camp whose presence at Toussaint's side has been corroborated, was only sixteen. Isaac Louverture, who lived in Bordeaux in the 1820s, was in touch with the former colonists living in the region, and his story is based in part on their testimony. It is not impossible that Charles Lamerenx provided Isaac with an embellished version of his role in the war. Whether or not the story is true, the important point is that it seemed plausible to Isaac: Charles Lamerenx, the son of a wealthy white planter, served on the staff of Toussaint Louverture when the black general waged war against the French republicans to uphold the rights of the Bourbon dynasty, and he stayed with his general when Toussaint decided to switch to the French republican side. $^{26}$

Charles Lamerenx lived a quiet and uneventful life in France after 1818. He died in the small town of Arette (in the Basses-Pyrénées) in 1854, at the age of seventy-nine. He had remained in touch with his brothers and sisters, all of whom save one had settled in Cuba. A few months before his death, his oldest son, Eugène, boarded the François et Théodore in Bordeaux and arrived in Havana on March 14, 1854. The Lamerenx family had prospered in Cuba. Charles's father, Jean-Pierre, had established a coffee plantation (cafetal San Pedro) a few miles south of the city of Matanzas with the help of his youngest son, François. Another son, along with a small group of Saint Domingue refugees, had introduced the cultivation of coffee to the Sierra del Rosario on the western part of the island (thanks in large part to migrants from Saint Domingue, Cuba became the leading coffee producer in the world in the 1830s). Eugène fell in love with his first cousin Rosa de Lamerens Pérez, married her, and settled in Cuba. ${ }^{27}$

Charles Lamerenx, born in colonial Saint Domingue in 1775, set foot in France for the first time in his life in 1818, at the age of forty-three, and sold the house where his father was born. He was only sixteen when the Haitian Revolution broke out. Between 1791 and 1818 , he was constantly on the move, fighting wars, trying to do business, or attempting to secure his own freedom. In her recent book, Atlantic Creoles in the Age of Revolutions, Jane Landers studies the trajectories of black sailors who crisscrossed the Atlantic in the early nineteenth century, repeatedly reinventing themselves amid fast-changing political and social circumstances. As Landers puts it, "the Atlantic creoles . . . fought variously for the King of Kongo, the King of England, the King of France, the French Jacobins, Muskogee and Seminole chiefs, the King of Spain, and sometimes for themselves. Each shift of allegiance required a reevaluation of political platforms and programs, with the possibilities

${ }^{26}$ For a recent mention of Lamerenx as an aide-de-camp to Louverture, see Jacques de Cauna, ed., Toussaint Louverture et l'indépendance d'Haïti (Toussaint Louverture and the independence of Haiti) (Paris, 2004), 200. Carlos Esteban Deive, Los Refugiados franceses en Santo Domingo (1789-1801) (The French refugees in Santo Domingo [1789-1801]) (Santo Domingo, 1984), 196.

27 Autos. Don Carlos Lamerens contra Don Mateo Grout sobre pesos (Proceedings. Don Carlos Lamerens versus Don Mateo Grout about money), 1807, file 685, no. 5 (National Archives of Cuba); Protocoles notariales (Notarial proceedings), 1840, Matanzas, Santiago López Villavicencio, notary public, vol. 2, pp. 589, 849, ibid. E. Tabío and R. Payarés, Sobre los cafetales coloniales de la Sierra del Rosario (On the colonial coffee plantations of the Rosario Mountains) (Havana, 1968). 
of freedom that each offered." A white man, Charles Lamerenx fits this characterization of the Atlantic creole. Buffeted by wars and revolutions, he pledged allegiance to Louis XVI of France, then to Charles IV of Spain, then to the French Republic, then to Ferdinand VII of Spain, then to Charles X of France, then to Louis Philippe of France. The only stable reference point in Lamerenx's movements was his family: his mother, then residing in Matanzas, Cuba, sent money to pay the court fees when he was tried and incarcerated by the Spanish. When he was released, he went to France, a country he had never seen before, because he and his siblings owned property there. After taking control of the estate of his ancestors, he tried to live the life he thought he should have had in Saint Domingue: he was the owner of a large rural estate that accommodated himself, his sister Marguerite, his brother-in-law, and his nephews. He even took a concubine Saint Domingue-style: not a slave woman, but a woman considerably below his station (the illiterate daughter of a local farmer). Such an arrangement would have been easily tolerated in eighteenth-century Saint Domingue or New Orleans, but it was not acceptable in nineteenth-century France. The other obvious difference was that a rural estate in southwestern France was not nearly as profitable as a coffee plantation based on slave labor. Charles was seemingly not a successful rural estate owner. In 1828 the Lamerenx siblings wrote from Cuba to remove their brother Charles as administrator of the family property and to place their sister Marguerite in his stead. Shortly thereafter Charles moved out of the family estate, applied for government support as a Saint Domingue refugee, married his companion Madeleine Biscay, and recognized the two sons he had with her. ${ }^{28}$

Charles Tilly has proposed the concept of "interpersonal trust networks" to describe migrant remittances between the United States, the Caribbean, and Latin America today. He observes that the flow of people, goods, and money goes both ways and shows that money from Latin America and the Caribbean is used to help buy real property in United States and vice versa. What makes this kind of cross-ownership possible are "trust networks" largely based on family ties, with an inverse relation between the geographical distance and the closeness of the kinship. You would not do business across the ocean with someone you do not know, but if your partner is a sibling or a cousin, the closeness of the family connection makes up for the physical distance, and you can effectively maintain business interests far from your place of residence. ${ }^{29}$

The concept of "trust network" is very apt for describing the activities of the Lamerenx family across the Atlantic world. After Charles arrived in France in 1818, he remained in touch with his siblings in Cuba, and the connection remained active for a long time, evidenced by his son sailing to Havana nearly forty years later and marrying his Cuban first cousin. During three generations in the nineteenth century, the Lamerenx functioned as one large family network with property holdings and business interests on both sides of the Atlantic. The siblings in Cuba were co-owners of the property in France. Charles and his sister, based in France, were co-owners of the coffee plantation in Matanzas until Charles sold his share to Marguerite. One could say that for Charles Lamerenx and his siblings the family horizon was co-extensive with the Atlantic horizon. ${ }^{30}$

28 Jane G. Landers, Atlantic Creoles in the Age of Revolutions (Cambridge, Mass., 2010), 7.

29 Charles Tilly, "Trust Networks in Transnational Migration," Sociological Forum, 22 (March 2007), 3-24.

30 Bienes de difuntos (Probate inventories), 1838, Matanzas, file 15, no. 319, Probate Inventories (National Archives of Cuba). Pierre Dilor, notary public, Saint-Palais, Jan. 17, 1834, 3 E 8760 (Archives of the PyrénéesAtlantiques Department). 


\section{From Slave Owners to Civil Rights Activists: Fanchonette Decoudreau's Descendants}

Charles Decoudreau and Margarita Castañedo had seven children. One of them, Joséphine (1802-1846), married Francisco de Paula de Trebiño, a.k.a. Paul Trévigne Sr. (17931851), in 1824. Their oldest son, Paul Trévigne Jr. (1825-1907), is listed in the African American National Biography published by Henry Louis Gates in 2008. Surprisingly, the entry states that we know nothing of Paul Trévigne's mother, "a woman known only as Découdreau." It turns out that Trévigne's mother, Joséphine Decoudreau, his grandmother Marguerite, and his great-grandmother Fanchonette, had all owned property in New Orleans, and the ownership records are available in the city's Notarial Archives. Paul Trévigne Jr.'s grandfather José Antonio de Paula de Trebiño, aka Joseph Trévigne (ca. 1765-1828), came to New Orleans from Plencia (a coastal town in the Spanish Basque province of Biscay) in the mid-1780s. He is listed as a "mariner" in the 1811 New Orleans directory and had been involved in the slave trade. Paul Trévigne Jr. was a teacher, author, journalist, and activist who taught at the Catholic School for Indigent Orphans, a private school for free blacks, endowed with money from the estate of Madame Couvent, née Marie Justine Cirnaire, a former slave who, according to local tradition, had been born in Guinea and was brought to New Orleans via Saint Domingue. Paul Trévigne Jr. was the editor of the New Orleans-based L'Union, a French-language newspaper that became an organ of the Louisiana Republican party in 1863 and advocated citizenship as well as universal suffrage for gens de couleurs and for the thousands of slaves who had been freed following the capture of New Orleans by Union forces in 1862. During Reconstruction, Trévigne advocated the same policies in the New Orleans Tribune. In his history of Black Reconstruction, W. E. B. Du Bois called the New Orleans Tribune "the first Negro daily in America." In the late 1870s, as the "separate but equal" doctrine was beginning to take shape, the new Democratic governor Francis T. Nicholls began to segregate New Orleans's previously integrated schools. Trévigne unsuccessfully fought this move by appealing to the Louisiana Supreme Court. His name does not appear among the members of the Comité des citoyens, the group that organized Homère Plessy's ill-fated challenge against Louisiana's "separate car" law, but he was very close to the group, and he remained involved in the fight as the editor of the French section of the New Orleans Daily Crusader from 1892 to $1896 .^{31}$

\section{Conclusion: Self-Reinvention and Local Belonging}

When Charles Lamerenx purchased the Bayou Road house in 1811, he was a former slave owner who had lost all his possessions in the Haitian Revolution and had to borrow

31 Justin Nystrom, "Trévigne (Paul)," in African American National Biography, ed. Henry Louis Gates Jr. and Evelyn Brooks Higginbotham (8 vols., Oxford, 2008), VII, 633. Whitney's New Orleans Directory and Louisiana \& Mississippi Almanac for the Year 1811. On José Antonio de Trebiño's role in the sale of slaves from Africa, see the sales record of Javier Perdomo, notary public, April 16, 1787, in Gwendolyn Midlo Hall, Louisiana Slave Records, 1719-1820, http://www.ibiblio.org/laslave/. On the New Orleans Tribune's editorial line and its political context, see Eric Foner, Reconstruction: America's Unfinished Revolution, 1863-1877 (New York, 1988), 62-65. W. E. B. Du Bois, Black Reconstruction in America, 1860-1880 (1935; New York, 1998), 456. Rebecca J. Scott, "Public Rights, Social Equality, and the Conceptual Roots of the Plessy Challenge," Michigan Law Review, 106 (March 2008), 777 804; Scott, "Atlantic World and the Road to Plessy v. Ferguson," 726-33. Desdunes, Our People and Our History, 66-68. 
money to complete the transaction. The seller, Charles Decoudreau, a free man of color, was relatively well-off and owned two slaves. New Orleans was in a period of explosive growth, following the arrival of massive numbers of refugees from Saint Domingue, which doubled the population of the city in just a few months. Real estate prices were high. The newly built house that Lamerenx bought from Decoudreau in 1811 was worth four times as much as the Lamerenx ancestral home in France. As a person of color, Decoudreau did not have the right to vote, but when he took his white adversary to court, he won the case. From a cursory look at the judgment, one could infer that the two men had very little in common: one was white and the other was black (this is at least how they would be categorized today); one was a newcomer to New Orleans and the other was a native of the city. Yet as Atlantic creoles both men had much in common. First of all, they spoke the same language: not only French, but also the same type of French creole. (Louisiana creole and Haitian creole are closely related languages, possibly descended from a French pidgin with a Wolof and Mandigo substrate spoken in Saint-Louis, Senegal, in the seventeenth century.) Second, Lamerenx's choice of neighborhood was no accident. His immediate neighbors on Bayou Road included Charles Decoudreau's sisters, free women of color, Louis de Morand, a wealthy white man who lived with Decoudreau's sister, and other wealthy whites. Whites and free-coloreds, living side by side, had close kinship and business ties. Third, the name the two Charleses probably called themselves was creole: in colonial French America, the word creole was used to designate any person born in the colony. Finally, they had similarities in their ancestry. Lamerenx belonged to minor French nobility; one of Decoudreau's grandparents was a slave from Senegambia who became the concubine of the wealthiest man in New Orleans and who later purchased her freedom from her French owner; the other three belonged to minor French nobility. According to the three-tiered system that became gradually more rigid during the first decades of the nineteenth century, Charles Lamerenx and Charles Decoudreau would have belonged to separate, racially defined castes. However, when they briefly met in 1811, these boundaries were only beginning to solidify and were not nearly as rigid as they became in the $1850 \mathrm{~s}^{32}$

One striking difference between the Lamerenx and Decoudreau families in this period is how much members of one moved around the Atlantic world and how little members of the other moved away from New Orleans. One might be tempted to say that the white family could afford to move while this possibility was not available to the free-colored family. This distinction does not hold, however. The Tinchant family, whose Atlantic peregrinations have been studied by Rebecca Scott and Jean Hébrard, was a family of free persons of color like the Decoudreaus, and what we have observed about the Lamerenx family (that their family's horizon was that of the Atlantic world) can also be said of the Tinchant family. There are many more examples of New Orleans free blacks emigrating to Europe in the nineteenth century, including Edmond Dédé (1827-1903), a classical composer who moved to Belgium in the 1850s and later to France, or Norbert Rillieux (18061894), who studied engineering in Paris, authored a key patent for sugar refining, and moved back to France in the late 1850s. Of the fifty free-coloreds whose lives are narrated in Desdunes's book, more than a dozen studied in Europe or settled there permanently. In 1840 the Tinchants purchased a farm near Pau, France, about fifty miles from the

32 Carl A. Brasseaux, French, Cajun, Creole, Houma: A Primer on Francophone Louisiana (Baton Rouge, 2005), 24. McWhorter, Missing Spanish Creoles, 172-76. Toledano and Louise-Christovich, New Orleans Architecture, 145. 
Lamerenx estate. The Tinchant sons were students in the lycée of Pau in the 1840s and early 1850s. Charles Lamerenx lived in Pau with his wife and sons in the late 1840s. His sons almost certainly were classmates of the Tinchant sons in the lycée. R. Darrell Meadows's study of social networks and the French Atlantic community shows that French migrants were surprised to come across familiar faces they had known on the other side of the Atlantic, and they experienced these encounters as amazing coincidences. If they met in the lycée of Pau, the Tinchant children and the Lamerenx children were able to share family stories from Saint Domingue, Cuba, and New Orleans. They were not alone in doing this: the list of prize winners for the lycée during those years reveals several students from Cuba and New Orleans (almost certainly families of refugees from Saint Domingue). ${ }^{33}$

These family histories support a strong but narrow concept of Atlantic creole history. One should recall here that Atlantic commerce and migration, however large a phenomenon, always concerned specific towns and regions. Even such a huge phenomenon as the slave trade, Gwendolyn Midlo Hall has shown, passed through a small number of coastal points and concerned a surprisingly small number of ethnicities. The historian Jacques de Cauna has shown that the French colonization of Saint Domingue was in many ways a regional story, and he has studied the disproportionate role of migrants from Gascony, Béarn, and the Basque country in the history of the colony. The Lamerenx travels took place between Saint Domingue, Cuba, New Orleans, Spain, North Africa, and the southwest of France (the ports being Bayonne or Bordeaux). They never included Paris or any other region of France. The migrants whose stories are told here belonged to a coherent Atlantic world, but one would miss the distinctiveness of this world if one tried to understand it too broadly. It was a world of coastal enclaves that had several distinguishing characteristics: it was multilingual, based on interpersonal trust networks, and focused on international trade (including the slave trade), and the slavery that was practiced there was different from large-scale plantation slavery. ${ }^{34}$

As we have seen, the free-coloreds in New Orleans gradually became a distinctive endogamous group. Traditionally, they had quasi-familial relations with their household slaves, and manumissions were frequent. With the hardening of racial categories and increasing legal obstacles to manumission, gens de couleur tended to identify with their European ancestry and to look down upon their African slaves. The opposite occurred as well: as discrimination against gens de couleur increased in nineteenth-century America (both in law and custom), some chose to identify with their African ancestry, even when that ancestry was a very small part of their family tree. Homère Plessy, who made an act of civil disobedience

\footnotetext{
33 Scott and Hébrard, "Rosalie of the Poulard Nation"; Scott and Hébrard, "Servitude, liberté et citoyenneté dans le monde atlantique des XVIIIe et XIXe siècles"; Scott and Hébrard, Freedom Papers; Scott, "Public Rights and Private Commerce"; Scott, "Atlantic World and the Road to Plessy v. Ferguson." Lester Sullivan, "Composers of Color of Nineteenth-Century New Orleans: The History behind the Music,” Black Music Research Journal, 8 (no. 1, 1988), 51-82. The Lamerenx family lived at 35 rue Gassies (now rue Carnot) in Pau from 1847 to 1851. See Biscay (Magdeleine) veuve Lamerens Duhard file, F/12/2751 (National Archives of France). R. Darrell Meadows, "Engineering Exile: Social Networks and the French Atlantic Community, 1789-1809," French Historical Studies, 23 (Winter 2000), 67-102. J. Delfour, Histoire du lycée de Pau (History of the lycée of Pau) (Pau, 1890), 413-60.

${ }_{34}$ Gwendolyn Midlo Hall, Slavery and African Ethnicities in the Americas: Restoring the Links (Chapel Hill, 2005), 55-79. De Cauna, L'Eldorado des Aquitains; Jacques de Cauna, "Amérique avant l'Amérique: Les Béarnais à SaintDomingue et dans la Caraïbe (XVIIe-XVIIIe siècles)" (America before America: The Béarnais in Saint-Domingue and the Caribbean [17th-18th centuries])," in L'Emigration basco-béarnaise aux Amériques au XIXe siècle (Basque and Béarnais emigration to the Americas in the 19th century), ed. Adrian Blazquez (Pau, 2000), 239-87.
} 
in 1892 by sitting in a railroad car reserved for whites, was an "octoroon": his ancestry was seven-eighths European and one-eighths African, and his apparent whiteness was meant to show the absurdity of the very notion of racial category. Paul Trévigne Jr. had African ancestors, including Nanette Dubreuil, a slave from Senegambia who had purchased her freedom in 1763, but most of his ancestors were European, including one of the French founders of New Orleans and a mariner from Spain who was involved in the slave trade. Jean-Charles Houzeau, who took over from Trévigne as editor of the New Orleans Tribune in 1864, described his predecessor as "a gay spirit with literary tastes" who had "descended from a Spanish father" and had "a little of the pride (the good kind) of a Castilian character." Trévigne's adamantly affirmed black identity was a deliberate choice. In the Faubourg Tremé documentary, Paul Trévigne is portrayed by a dark-skinned African American. This choice makes sense, given Trévigne's affirmation of an African identity and the fact that his descendants suffered the same legal discrimination as the rest of the southern black population in the twentieth century (as explained by Irving Trevigne in the documentary). What the documentary does not clearly convey, however, is that New Orleans gens de couleur experienced the abolition of slavery with mixed emotions. On the one hand, they welcomed it and allied themselves with the former slaves to claim equal rights for all (a stance from which the New Orleans Tribune never departed). On the other hand, not everyone in the free-colored group had initially sided with the Union. Armand Lanusse, the director of the private school for free blacks where Paul Trévigne taught, had been a captain in the Confederate army, and he refused to follow Gen. Benjamin Butler's 1862 order to fly the Union flag over the school. After emancipation, no legal basis existed for the distinctiveness of gens de couleur, making it increasingly difficult for them to hold on to a separate identity. For many, the solution was chain migration to northern cities and California, with continued endogamy and the preservation of small groups of interlocked families who defined themselves as neither white nor black but creole-a term contested in Louisiana (whites had appropriated it to designate Louisianans of "pure" French or Spanish ancestry) and that carried little meaning elsewhere. These groups continued to own property in New Orleans, thus forming "continental" family networks similar to the long-standing Atlantic family networks. ${ }^{35}$

The documentary presents Tremé as "arguably the oldest black neighborhood in America." The continuity affirmed in this statement has great symbolic power, and its truth is rooted in in the alliance between gens de couleur and freedmen advocated by Paul Trévigne during Reconstruction. From a micro-historical point of view, however, the district experienced much less continuity. By the end of nineteenth century, most gens de couleur had moved out of Tremé and had been replaced by Italian immigrants; by the 1940s many gens de couleur had left Louisiana and moved to California. Tremé became a black neighborhood again in the 1960s through an influx of "Anglo" blacks (descendants of English-speaking

35 One newspaper asserted that free-coloreds "regard the slave with more disdain and antagonism than the white man." See New Orleans Daily Delta, July 17, 1852, quoted in Foner, "Free People of Color in Louisiana and St. Domingue," 429. Mark Elliott, "Race, Color Blindness, and the Democratic Public: Albion W. Tourgée's Radical Principles in Plessy v. Ferguson,” Journal of Southern History, 67 (May 2001), 287-330. Jean-Charles Houzeau, My Passage at the New Orleans Tribune: A Memoir of the Civil War Era, ed. David C. Rankin, trans. Gerard F. Denault (Baton Rouge, 1984), 71n6. Desdunes, Our People and Our History, 13-24. Brasseaux, French, Cajun, Creole, Houma, 85-115; James H. Dormon, "Louisiana's 'Creoles of Color': Ethnicity, Marginality, and Identity," Social Science Quarterly, 73 (Sept. 1992), 615-26; Frances Jerome Woods, Marginality and Identity: A Colored Creole Family through Ten Generations (Baton Rouge, 1972). 
freed slaves) who, according to the historian Carl Brasseaux, are now "the most visible standard bearers of south Louisiana's ongoing Creole revival."36

In his study of Anna Madgigine Jai Kinsley, an African princess who became a slave and eventually a plantation slave owner in Florida, Daniel Schafer mentions the ideas of Anna Madgigine's owner, who "advocated humane treatment and encouraged slaves to live in family units and perpetuate their African customs" and "called for liberal manumission laws and policies" so that "once united, whites and free blacks would be able to control the much larger group of enslaved blacks whose labor created the riches that justified the overall system." 37 When set against the norms of the plantation system of the southern United Sates, these ideas seem strange and idiosyncratic. When compared with the family stories told in this study, they appear as a belated manifestation of the Atlantic creole model that was once the norm in New Orleans and gradually disappeared in the first decades of the nineteenth century. The controversies regarding the role of African culture and customs in the emergence of a distinctive African American culture pit those who argue for the importance of African models against those who tend to see Africa as a residual presence or an imagined past. The Atlantic creoles whose stories are told here suggest something entirely different: a major African presence, not because African models were "imported" (or not) via the slave trade but because there were many social and cultural similarities between the coastal enclaves (including those in Africa) involved in transatlantic commerce.

We can see two opposite tendencies in the behavior of Atlantic creoles: on the one hand, they demonstrated extreme mobility and an ability to reinvent themselves after moving to new places across the ocean; on the other hand, they also showed a strong sense of local belonging, grounded in land ownership. In other words, being creole meant being a native, a frequent traveler, and a new settler, all at the same time. This phenomenon can be explained by the origins of creole culture (and probably of creole languages) in coastal enclaves, in Africa first, then in the Americas. Coastal enclaves were small, face-to-face communities: people knew each other's family history, allegiances were strictly local, and the way of life was urban and profoundly different from the rural life of the hinterland. Being a native of an enclave meant being born into a culture that was experienced as both small and unique. At the same time, as Ira Berlin puts it, Atlantic creoles had a "genius for intercultural negotiation" that "was central to a way of life that transcended particular venues." A woman born in Gorée, Marie Adélaïde Rossignol, the daughter of a signare, could thrive in Cap-Français, where in 1786 she married Guillaume Dumont, a surgeon from Gascony, because the language, customs, and social structures were broadly similar (the couple settled in Charleston, another Atlantic creole enclave, after the Haitian Revolution). Similarly, a young Frenchman born in Bordeaux in 1789, Justin Devès, could travel to New Orleans and Philadelphia, and eventually build a commercial fortune after marrying a signare, Magdeleine Philipp, in Saint-Louis, Senegal. According to Desdunes, who wrote in 1911 with an indigenous knowledge of creole tradition (and an aristocratic tendency to idealize the past), migration into Louisiana took a different turn after 1840 as "newcomers to New Orleans from faraway shores... . were not of the same mentality as the earlier people, who came from

36 Faubourg Tremé. On changes in the Tremé neighborhood, see "Chronology of Church History," St. Augustine Catholic Church of New Orleans, http://www.staugustinecatholicchurch-neworleans.org/hist-chron.htm. Brasseaux, French, Cajun, Creole, Houma, 112.

37 Schafer, Anna Madgigine Jai Kinsley, 32. 
chivalric origins and who preserved the ideals of their class." These newcomers "utilized slavery as their main source of revenue. Every enterprise, every transaction revolved around slavery: business, politics, and even religion." Once a society with slaves, New Orleans had become a slave society. The circulation of creoles across the Atlantic became a thing of the past, and Desdunes felt the need to justify a behavior that was no longer seen as natural: "The man of color can, without appearing ridiculous, entertain ideas of exchanging residence to relieve his circumstances just as other human beings do. The love of self, the love of one's family, and of one's kind should be as strong as the love of one's country." 38 